\title{
Influence of Charging Current and Potential Drop on the Propagation of the Change in the Membrane Potential
}

\section{$\operatorname{AUTHOR}(\mathrm{S}):$}

Kushida, Yuki; Shirai, Osamu; Kitazumi, Yuki; Kano, Kenji

\section{CITATION:}

Kushida, Yuki ... [et al]. Influence of Charging Current and Potential Drop on the

Propagation of the Change in the Membrane Potential. Electroanalysis 2014, 26(8): 18581865

\section{ISSUE DATE:}

2014-07-16

URL:

http://hdl.handle.net/2433/200628

\section{RIGHT:}

This is the peer reviewed version of the following article: Kushida, Y., Shirai, O., Kitazumi, Y. and Kano, K. (2014), Influence of Charging Current and Potential Drop on the Propagation of the Change in the Membrane Potential. Electroanalysis, 26: 1858-1865, which has been published in final form at http://dx.doi.org/10.1002/elan.201400195. This article may be used for non-commercial purposes in accordance with Wiley Terms and Conditions for SelfArchiving.; This is not the published version. Please cite only the published version.; この論文は出版社版でありません 
Influence of charging current and potential drop on the propagation of the change in the membrane potential

Yuki Kushida, Osamu Shirai*, Yuki Kitazumi, and Kenji Kano

Division of Applied Life Sciences, Graduate School of Agriculture, Kyoto University, Sakyo, Kyoto 606-8502, Japan

Keywords: Liquid membrane; Membrane potential; Ion transport; Propagation; Potentiometry; Capacitance; $i R$ drop

*Corresponding Author. Address: Division of Applied Life Sciences, Graduate School of Agriculture, Kyoto University, Sakyo, Kyoto 606-8502, Japan. Tel: +81-75-753-6394; Fax: $+81-75-753-6456$

E-mail address: shiraio@kais.kyoto-u.ac.jp (O. Shirai). 


\begin{abstract}
Propagation of a change in a potential difference between two aqueous phases (W1 and W2) across a membrane ( $\left.E_{\mathrm{W} 1-\mathrm{W} 2}\right)$ was examined by using three membrane cells (A, B and C). By controlling the ionic compositions, $E_{\mathrm{W} 1-\mathrm{W} 2}$ of $\mathrm{A}\left(E_{\mathrm{W} 1-\mathrm{W} 2, \mathrm{~A}}\right)$ was identical with $E_{\mathrm{W} 1-\mathrm{W} 2}$ of $\mathrm{C}$ $\left(E_{\mathrm{W} 1-\mathrm{W} 2, \mathrm{C}}\right)$ and $E_{\mathrm{W} 1-\mathrm{W} 2}$ of $\mathrm{B}\left(E_{\mathrm{W} 1-\mathrm{W} 2, \mathrm{~B}}\right)$ was different from $E_{\mathrm{W} 1-\mathrm{W} 2, \mathrm{~A}}$. Changing the connection with $\mathrm{C}$ from $\mathrm{A}$ to $\mathrm{B}, E_{\mathrm{W} 1-\mathrm{W} 2, \mathrm{C}}$ varied from $E_{\mathrm{W} 1-\mathrm{W} 2, \mathrm{~A}}$ to the potential close to $E_{\mathrm{W} 1-\mathrm{W} 2, \mathrm{~B}}$. The delay and decrement of the propagation was observed by setting capacitors or resistors in the electric circuit.
\end{abstract}

(Received: , Accepted: ) 


\section{Introduction}

The membrane potential of the nerve cell is usually determined by the ratio of the $\mathrm{K}^{+}$ concentration of the inside to that of the outside under the normal conditions, and it is called the rest potential [1-7]. When the specific receptor receives neurotransmitters at the synapse, $\mathrm{Na}^{+}$is mainly transported from the outside to the inside through the ligand-dependent channels [6,7]. The transport of $\mathrm{Na}^{+}$provokes the change in the membrane potential, and it is named the action potential. Then the voltage-gated $\mathrm{Na}^{+}$channels of which open-times are short (about $1 \mathrm{~ms}$ ) open one after another around the active site, and the active site spreads along the axon. On the other hand, $\mathrm{K}^{+}$is transported from the inside to the outside of the nerve cell by opening the delayed $\mathrm{K}^{+}$channels, and the membrane potential of the active site goes back to the rest potential. Thus, the active site moves along the axon toward the axon terminal (synapse), as shown in scheme 1 . The arrival of the active potential at the synapse causes the fusion of synaptic vesicles containing neurotransmitters with the nervous membrane, and the neurotransmitters are released to the outside of the neuron cell at the synapse. By the capture of the neurotransmitters at the synapse of the next neuron cell, the nerve transmission continues successively. When the inflow of $\mathrm{Na}^{+}$at the sending-site is not enough, the change in the membrane potential does not propagate to the nerve terminal $[1,2,8]$. As for the decrement or the delay in the propagation of the active potential, it has been proposed that the decrement or the delay is caused by the electric charging at the surface of lipid bilayers and the ohmic drop within the aqueous solutions inside and outside the cell [9-15]. Although there are many works conducted on the propagation of active site by measuring the local current along the axon [7], the propagation of the active potential along the axon has not been directly observed yet. Thus, the quantitative evaluation on the relation between the membrane potential and the local current at each microscopic domain has not been experimentally given.

In previous works $[16,17]$, our group has proposed a new propagation mechanism of the 
change in the membrane potential by use of a U-shaped organic liquid membrane cell system of which interfacial potentials were determined by the transport of two ionic species such as $\mathrm{Na}^{+}$ and tetraethylammonium ion $\left(\mathrm{TEA}^{+}\right)$. The U-shaped cell was prepared to mimic two adjacent nodes of Ranvier. As a result, the propagation of the active potential was observed and we found the threshold was present in the same manner as the propagation of action potential. By considering the electroneutrality principle and the mass balance of electrolyte ions in every phase, the relation between the propagation of the active potential and the circulating current between the sending-site and the receiving-site can be explained. Although we recognize that the magnitude of the ion transport current caused at the sending-site is important for the propagation of the active potential, the influence of the ohmic drop due to the solution resistance and of the charging current due to the formation of the surface double layer on the propagation of the active potential could not be clearly analyzed.

In the present work, the influence of the charging current and the ohmic drop on the propagation of the active potential is elucidated by use of capacitors and resistors. Thus, it is proved that the decrement and the delay of the propagation of the active potential are caused by the charging current and the ohmic drop.

\section{Experimental}

\subsection{Chemicals}

Sodium tetrakis[3,5-bis(trifluoromethyl)phenyl]borate (NaTFPB) was prepared in a manner similar to that reported previously [18]. The TFPB ${ }^{-}$salts of Bis(triphenylphosphoranylidene)ammonium (BTPPATFPB) and tetraethylammonium (TEATFPB) were obtained by mixing a methanol solution of NaTFPB with a methanol solution of BTPPACl (Sigma-Aldrich Co.) or TEACl (Wako Pure Chemical Co.), respectively. The precipitates of BTPPATFPB or TEATFPB were purified by the recrystallization based on the temperature dependence of the solubility of the salt in ethanol. 1,2-Dichloroethane (DCE) was 
purchased from Wako Pure Chemical Co. All other chemicals were of analytical reagent grade and used without further purification.

\subsection{Apparatus}

Potentiometric measurements were performed on a potentiostat/galvanostat model HA-1010mM4A (Hokuto Denko Co.) and an A/D converter model GL900 (Graphtec Co.). The circulating current was measured by an ammeter HM-103 (Hokuto Denko Co.). The ammeter was connected to the lead wires to measure the circulating current in the circuit. A rotary switch M43 (Alps Electric Co.) was placed within the electric circuit of the present cell system, as shown in Fig. 1(a).

\subsection{Electrochemical measurements}

The propagation of a change in a potential difference across a liquid membrane (M) was investigated by use of a cell system combined with three liquid membrane cells (A, B and C) which were composed of two aqueous phases (W1 and W2) and 1,2-dichloroethane phases, respectively. The liquid membrane cell system was composed of two aqueous phases (W1 and W2) and two 1,2-dichloroethane (DCE) phases (M1 and M2) as illustrated in Fig. 1(b). The respective W1 (and W2) phases of three cells were electrically connected through lead wires by inserting $\mathrm{Ag} \mid \mathrm{AgCl}$ electrodes into every aqueous phase.

The ionic composition of one potential-sending cell (A) and one potential-receiving cell (C) were noted by cell (1).

\begin{tabular}{c|c|c} 
W1 & $\mathrm{M}$ & W2 \\
& $10^{-2} \mathrm{M}$ TEATFPB & $5 \times 10^{-3} \mathrm{M}$ TEACl \\
$0.1 \mathrm{M} \mathrm{NaCl}$ & $2.5 \times 10^{-5} \mathrm{M}$ NaTFPB & $0.1 \mathrm{M} \mathrm{NaCl}$ \\
$3 \%$ agar & $10^{-2} \mathrm{M}$ BTPPATFPB & $3 \%$ agar \\
(RE1) & (RE2, RE3) & (RE4)
\end{tabular}


On the other hand, the cell configuration of another potential-sending cell (B) was presented by cell (2).

\begin{tabular}{c|c|c} 
W1 & $\mathrm{M}$ & W2 \\
$5 \times 10^{-3} \mathrm{M} \mathrm{TEACl}$ & $10^{-2} \mathrm{M}$ TEATFPB & $5 \times 10^{-3} \mathrm{M}$ TEACl \\
$0.1 \mathrm{M} \mathrm{NaCl}$ & $2.5 \times 10^{-5} \mathrm{M}$ NaTFPB & $0.1 \mathrm{M} \mathrm{NaCl}$ \\
$3 \%$ agar & $10^{-2} \mathrm{M}$ BTPPATFPB & $3 \%$ agar \\
(RE1) & (RE5) & (RE4)
\end{tabular}

The membrane phase which consisted of DCE (2 ml each) containing $10^{-2} \mathrm{M}$ TEATFPB, $10^{-2}$ M BTPPATFPB and $2.5 \times 10^{-5} \mathrm{M}$ NaTFPB were put between $\mathrm{W} 1$ (3 ml) and W2 (3 ml). Each of six $\mathrm{Ag} \mid \mathrm{AgCl}$ electrodes was immersed in $\mathrm{W} 1$ and $\mathrm{W} 2$ of the cells $\mathrm{A}, \mathrm{B}$ and $\mathrm{C}$, and three $\mathrm{TEA}^{+}$ selective electrodes (TEA-ISE, RE2, RE3 and RE5) in each M of the cells A, B and C [19]. Cell (3) shows the TEA-ISE configuration.

$$
\text { Ag|AgCl|5 mM TEA }{ }^{+} \mathrm{Cl}^{-} \|(\mathrm{M})
$$

Because the respective W1 (and W2) phases of three cells were electrically connected through lead wires, the potential difference was hardly generated between W1 (W2) of the cell A or B and W1 (W2) of the cell C. Therefore, the reference electrodes in W1 and W2 of each cell were described as RE1 and RE4, respectively. The potential differences at the $\mathrm{W} 1 \mid \mathrm{M}$ and $\mathrm{W} 2 \mid \mathrm{M}$ interfaces ( $E_{\mathrm{W} 1 \mid \mathrm{M}}$ and $\left.E_{\mathrm{W} 2 \mid \mathrm{M}}\right)$ of the cells A, B and C were indicated as the potentials of RE1 and RE4 vs. the TEA-ISE of each cell. Since W1, W2 and M contain sufficient electrolytes, the potential difference between $\mathrm{W} 1$ and $\mathrm{W} 2\left(E_{\mathrm{W} 1-\mathrm{W} 2}\right)$ can be expressed by both $E_{\mathrm{W} 1 \mid \mathrm{M}}$ and $E_{\mathrm{W} 2 \mid \mathrm{M}}$, as given below.

$$
E_{\mathrm{W} 1-\mathrm{W} 2}=E_{\mathrm{W} 1 \mid \mathrm{M}}-E_{\mathrm{W} 2 \mid \mathrm{M}}
$$

As for the influence of some capacitors or some electric resistors on the propagation of the change in the membrane potential, some capacitors or some resistors were set in the electric circuit, as represented in Fig. 1(a). 


\section{Results and discussion}

2.1 The propagation of the change in the membrane potential caused by the circulating current Figure 2(a) indicates the time courses of $E_{\mathrm{W} 1-\mathrm{W} 2}$ of the cell B ( $E_{\mathrm{W} 1-\mathrm{W} 2, \mathrm{~B}}$; dotted) and the cell C ( $E_{\mathrm{W} 1-\mathrm{W} 2, \mathrm{c}}$; solid), observed simultaneously in the cell system. The time-courses of $E_{\mathrm{W} 1 \mid \mathrm{M}}$ of the cell B ( $E_{\mathrm{W} 1 \mid \mathrm{M}, \mathrm{B}}$; dashed), $E_{\mathrm{W} 2 \mid \mathrm{M}}$ of the cell B ( $E_{\mathrm{W} 2 \mid \mathrm{M}, \mathrm{B}}$; dotted $), E_{\mathrm{W} 1 \mid \mathrm{M}}$ of the cell C $\left(E_{\mathrm{W} 1 \mid \mathrm{M}, \mathrm{C}}\right.$; broken) and $E_{\mathrm{W} 2 \mid \mathrm{M}}$ of the cell C ( $E_{\mathrm{W} 2 \mid \mathrm{M}, \mathrm{C}}$; solid) are shown in Fig. 2(b). At first, the cell C was connected with the cell A. Since the ionic composition of the cell A was identical with that of the cell $\mathrm{C}$, the current (i) did not flow at each interface before the changing the switch from the cell A to the cell B, as represented in Fig. 2(c). Accordingly, $E_{\mathrm{W} 1-\mathrm{W} 2, \mathrm{~A}}$ at $i=0 \mathrm{~A}\left(E_{\mathrm{W} 1-\mathrm{W} 2, \mathrm{~A}}{ }^{0}\right)$ was almost equal to $E_{\mathrm{W} 1-\mathrm{W} 2, \mathrm{C}}$ at $i=0 \mathrm{~A}\left(E_{\mathrm{W} 1-\mathrm{W} 2, \mathrm{C}}\right)$. Then, $E_{\mathrm{W} 1 \mid \mathrm{M}, \mathrm{C}}$ at $i=0 \mathrm{~A}\left(E_{\mathrm{W} 1 \mid \mathrm{M}, \mathrm{C}}{ }^{0}\right)$ and $E_{\mathrm{W} 2 \mid \mathrm{M}, \mathrm{C}}$ at $i=0 \mathrm{~A}\left(E_{\mathrm{W} 2 \mid \mathrm{M}, \mathrm{C}^{0}}\right)$ were also identical with $E_{\mathrm{W} 1 \mid \mathrm{M}, \mathrm{A}}$ at $i=0 \mathrm{~A}\left(E_{\mathrm{W} 1 \mid \mathrm{M}, \mathrm{A}}{ }^{0}\right)$ and $E_{\mathrm{W} 2 \mid \mathrm{M}, \mathrm{A}}$ at $i=0 \mathrm{~A}$ $\left(E_{\mathrm{W} 2 \mid \mathrm{M}, \mathrm{A}}{ }^{0}\right)$, respectively. After the connection with the cell C was changed from the cell A to the cell B, $E_{\mathrm{W} 1-\mathrm{W} 2, \mathrm{~B}}$ and $E_{\mathrm{W} 1-\mathrm{W} 2, \mathrm{C}}$ varied from 0.040 and $0.330 \mathrm{~V}\left(E_{\mathrm{W} 1-\mathrm{W} 2, \mathrm{~B}}{ }^{0}\right.$ and $\left.E_{\mathrm{W} 1-\mathrm{W} 2, \mathrm{C}}{ }^{0}\right)$ to 0.080 and $0.090 \mathrm{~V}$, respectively. Simultaneously, $E_{\mathrm{W} 1 \mid \mathrm{M}, \mathrm{B}}, E_{\mathrm{W} 2 \mid \mathrm{M}, \mathrm{B}}, E_{\mathrm{W} 1 \mid \mathrm{M}, \mathrm{C}}$ and $E_{\mathrm{W} 2 \mid \mathrm{M}, \mathrm{C}}$ changed from $-0.025,-0.070,0.260$ and $-0.070 \mathrm{~V}\left(E_{\mathrm{W} 1 \mid \mathrm{M}, \mathrm{B}}{ }^{0}, E_{\mathrm{W} 2 \mid \mathrm{M}, \mathrm{B}}{ }^{0}, E_{\mathrm{W} 1 \mid \mathrm{M}, \mathrm{C}^{0}}\right.$ and $\left.E_{\mathrm{W} 2 \mid \mathrm{M}, \mathrm{C}^{0}}\right)$ to $-0.010,-0.100$, -0.025 and $-0.060 \mathrm{~V}$, respectively. The circulating current flowed after changing the switch from the cell A to the cell B, as shown in Fig. 2(c). Under the conditions, the difference between $E_{\mathrm{W} 1 \mid \mathrm{M}, \mathrm{B}}$ and $E_{\mathrm{W} 1 \mid \mathrm{M}, \mathrm{c}}$ and that between $E_{\mathrm{W} 2 \mid \mathrm{M}, \text { в }}$ and $E_{\mathrm{W} 2 \mid \mathrm{M}, \mathrm{C}}$ seemed to be caused by the generation of the circulating current [17]. The steep current flowed just after the switch change might be attributed to both the electric charging and the concentration depolarization at the interfaces [17].

Figure 3 illustrates imaginary steady-state voltammograms of ion transfer of both $\mathrm{Na}^{+}$and $\mathrm{TEA}^{+}$by considering the transfer energies of $\mathrm{Na}^{+}$and $\mathrm{TEA}^{+}$from $\mathrm{W}$ to DCE $(0.591$ and $0.019 \mathrm{~V}$ vs. TPhE, respectively) and their concentrations [20]. In this cell system, the transfer of $\mathrm{Na}^{+}$or $\mathrm{TEA}^{+}$from W (W1 and W2) to DCE (M) gives the positive current. In contrast, the transfer of $\mathrm{Na}^{+}$or TEA ${ }^{+}$from DCE to $\mathrm{W}$ generates the negative current. The potential window is regulated 
by both the transport of $\mathrm{Na}^{+}$from $\mathrm{W}$ to DCE and that of TEA ${ }^{+}$from DCE to W. The existence of $\mathrm{Na}^{+}$in DCE or that of TEA ${ }^{+}$in $\mathrm{W}$ causes the negative or the positive current, respectively, within the potential window. The gray and black solid curves in Fig. 3(a) show the voltammograms at the W1|M interface of the cells A and B, respectively. The solid line in Fig. 3(b) indicates the voltammogram at the W1|M interface of the cell C. Similarly, the solid line in Fig. 3(c) represents the voltammograms at the $\mathrm{W} 2 \mid \mathrm{M}$ interfaces of the cells $\mathrm{A}$ and $\mathrm{B}$, and the solid line in Fig. 3(d) is the voltammogram at the W2|M interface of the cell C. In respective figures, $E_{\mathrm{W} 1 \mid \mathrm{M}, \mathrm{A}}{ }^{0}, E_{\mathrm{W} 2 \mid \mathrm{M}, \mathrm{A}^{0}}, E_{\mathrm{W} 1 \mid \mathrm{M}, \mathrm{C}^{0}}$ and $E_{\mathrm{W} 2 \mid \mathrm{M}, \mathrm{C}^{0}}$ are illustrated with the open circles. Since the ionic composition of the cell $\mathrm{A}$ is identical with that of the cell $\mathrm{C}, E_{\mathrm{W} 1 \mid \mathrm{M}, \mathrm{A}^{0}}$ is identical with $E_{\mathrm{W} 1 \mid \mathrm{M}, \mathrm{C}^{0}}$. Then, $E_{\mathrm{W} 1 \mid \mathrm{M}, \mathrm{A}^{0}}$ and $E_{\mathrm{W} 1 \mid \mathrm{M}, \mathrm{C}^{0}}$ are determined by the distribution of $\mathrm{Na}^{+}$between $\mathrm{W} 1$ and M. On the other hand, $E_{\mathrm{W} 2 \mid \mathrm{M}, \mathrm{A}^{0}}$ and $E_{\mathrm{W} 2 \mid \mathrm{M}, \mathrm{C}^{0}}$ are controlled by the distribution of $\mathrm{TEA}^{+}$between $\mathrm{W} 2$ and $\mathrm{M}$, and $E_{\mathrm{W} 2 \mid \mathrm{M}, \mathrm{A}^{0}}$ is equal to $E_{\mathrm{W} 2 \mid \mathrm{M}, \mathrm{C}^{0}}$.

After changing the connection with the cell C from the cell A to the cell $\mathrm{B}$, the imaginary steady-state voltammogram at the W1|M interface of the sending site changed from the gray solid line to the black solid line. This is because the transfer of TEA ${ }^{+}$from $\mathrm{W} 1$ to $\mathrm{M}$ is much easier than that of $\mathrm{Na}^{+}$. When the concentration of TEA ${ }^{+}$in W1 is much higher than that of $\mathrm{Na}^{+}$ in $\mathrm{M}, \mathrm{Na}^{+}$is replaced by $\mathrm{TEA}^{+}$as a potential-determining ion at the $\mathrm{W} 1 \mid \mathrm{M}$ interface [16]. Consequently, the potential balance in the electric circuit was broken by the switch change, though the imaginary steady-state voltammograms at the W1|M interface of the receiving site (the cell C), the W2|M interface of the sending site (the cell B) and the W2|M interface of the receiving site (the cell C) remained. Then, every interfacial potential mutually varied to keep the electroneutrality within the whole cell. Since the positive current $\left(i_{0}\right)$ due to the transfer of TEA ${ }^{+}$ from W1 to $\mathrm{M}$ flowed at the W1|M interface of the cell B, the transfer of $\mathrm{Na}^{+}$or $\mathrm{TEA}^{+}$occurred at other interfaces so that an electric current didn’t totally flow between W1 and W2. In this case, the negative current $\left(-i_{0}\right)$ due to the transfer of not only $\mathrm{Na}^{+}$but also TEA ${ }^{+}$from M to W2 was generated at the W2|M interface of the cell B. In addition, the negative current $\left(-i_{0}\right)$ due to both 
the transfer of $\mathrm{Na}^{+}$from $\mathrm{M}$ to $\mathrm{W} 1$ and that of $\mathrm{TEA}^{+}$from $\mathrm{M}$ to $\mathrm{W} 1$ at the W1|M interface of the cell $\mathrm{C}$ and the positive current $\left(i_{0}\right)$ due to the transfer of TEA ${ }^{+}$from W2 to M (containing the transfer of $\mathrm{Na}^{+}$from $\mathrm{M}$ to W2) were generated at the W2|M interface of the cell C. In order to maintain the electroneutrality, the magnitudes of these currents were equivalent each other. Although the current didn't flow between W1 and W2 as a whole, the circulating current $\left(i_{0}\right)$ was generated at each interface in the cell system as reported by a previous work [17]. When $E_{\mathrm{W} 1 \mid \mathrm{M}}$ of the sending-site varied from $E_{\mathrm{W} 1 \mid \mathrm{M}, \mathrm{A}}^{0}$ to $E_{\mathrm{A}}, E_{\mathrm{W} 1 \mid \mathrm{M}, \mathrm{C}}$ varied from $E_{\mathrm{W} 1 \mid \mathrm{M}, \mathrm{C}^{0}}$ to $E_{\mathrm{B}}$. At the same time, $E_{\mathrm{W} 2 \mid \mathrm{M}}$ of the sending-site and $E_{\mathrm{W} 2 \mid \mathrm{M}, \mathrm{C}}$ turned from $E_{\mathrm{W} 1 \mid \mathrm{M}, \mathrm{B}}{ }^{0}$ and $E_{\mathrm{W} 1 \mid \mathrm{M}, \mathrm{C}^{0}}$ to $E_{\mathrm{C}}$ and $E_{\mathrm{D}}$, respectively. As a result, $E_{\mathrm{A}}$ and $E_{\mathrm{C}}$ became more negative than $E_{\mathrm{B}}$ and $E_{\mathrm{D}}$, respectively. Because $E_{\mathrm{W} 1 \mid \mathrm{M}, \mathrm{B}}, E_{\mathrm{W} 2 \mid \mathrm{M}, \mathrm{B}}, E_{\mathrm{W} 1 \mid \mathrm{M}, \mathrm{C}}$ and $E_{\mathrm{W} 2 \mid \mathrm{M}, \mathrm{C}}$ mutually changed to keep the electroneutrality in every phase, we have concluded that the propagation of the change in the membrane potential was caused by the generation of the circulating current within the membrane system. The overshoots of the change in $E_{\mathrm{W} 1 \mid \mathrm{M}, \mathrm{B}}, E_{\mathrm{W} 2 \mid \mathrm{M}, \mathrm{B}}$ and $E_{\mathrm{W} 2 \mid \mathrm{M}, \mathrm{c}}$ appeared just after the switch change. Because the shift of $E_{\mathrm{W} 1 \mid \mathrm{M}, \mathrm{C}}$ was much larger than those of $E_{\mathrm{W} 1 \mid \mathrm{M}, \mathrm{B}}, E_{\mathrm{W} 2 \mid \mathrm{M}, \text { в }}$ and $E_{\mathrm{W} 2 \mid \mathrm{M}, \mathrm{C}}$, it is considered that $E_{\mathrm{W} 1 \mid \mathrm{M}, \mathrm{B}}, E_{\mathrm{W} 2 \mid \mathrm{M}, \text { в }}$ and $E_{\mathrm{W} 2 \mid \mathrm{M}, \mathrm{C}}$ were affected by the charging current at the W1|M interface of the cell B just after the switch changed. Thus, the appearance of the sharp current-peak might result from the magnitude of not only the Faradaic current but also the charging current at the W1|M and W2|M interfaces of the cells B and C. In this case, the magnitude of the steady-state current ( $i_{0}$ ) depended on the concentration of $\mathrm{TEA}^{+}$in $\mathrm{M}$ of the cell $\mathrm{B}$. On the basis of these properties, the effect of resistances and condensers within the electric circuit is discussed as follows.

3.2 The influence of the resistance of the cell on the propagation of the change in the membrane potential

Curves 1 to 9 of Fig. 4(a) represent the time courses of $E_{\mathrm{W} 1-\mathrm{W} 2 \text {, c }}$ in which some electric resistances $(R=0,10,21,31,56,110,165,360$ and $567 \mathrm{k} \Omega$, respectively) were connected within the cell system. Similarly, curves 10 to 18 of Fig. 4(a) are the time courses of $E_{\mathrm{W} 1-\mathrm{W} 2, \mathrm{~B}}$, 
when the resistances used are $0,10,21,31,56,110,165,360$ and $567 \mathrm{k} \Omega$, respectively. Since the cell $\mathrm{C}$ was connected with the cell A before the switch change, $E_{\mathrm{W} 1-\mathrm{W} 2, \mathrm{C}^{0}}$ was almost identical with $E_{\mathrm{W} 1-\mathrm{W} 2, \mathrm{~A}^{0}}$ and the circulating current did not flow. Just after the switch change, $E_{\text {W1-W2, C }}$ shifted to the negative direction. In particular, the influence of the resistances on the change in $E_{\mathrm{W} 1 \mid \mathrm{M}, \mathrm{C}}$ was significant. The time courses of $E_{\mathrm{W} 1 \mid \mathrm{M}, \mathrm{C}}$ are represented as curves 1 to 9 of which electric resistances were $0,10,21,31,56,110,165,360$ and $567 \mathrm{k} \Omega$, respectively, in Fig. 4(b). Curves 1 to 9 in Fig. 4(c) show time-dependences of the circulating current observed in the same cell system. At $R=0 \Omega$, a large current peak (about $25 \mu \mathrm{A}$ ) appeared and it was settled down to a current of approximately $7 \mu \mathrm{A}$. The electric current in the case of $R=10 \mathrm{k} \Omega$ was about $4 \mu \mathrm{A}$ about $20 \mathrm{~s}$ after the switch change. Because the difference between the current height in the case of $R=0 \Omega$ and that in the case of $R=10 \mathrm{k} \Omega$ is about $3 \mu \mathrm{A}$ about $20 \mathrm{~s}$ after the switch change, the estimated $i R$ drop (about $0.030 \mathrm{~V})$ due to the insertion of the resistance $(R=$ $10 \mathrm{k} \Omega$ ) is in good agreement with the experimental value (about $0.030 \mathrm{~V}$ ). At that time, the difference of $E_{\mathrm{W} 1 \mid \mathrm{M}, \mathrm{C}}$ was about $0.025 \mathrm{~V}$. When $R=567 \mathrm{k} \Omega$ was connected with the electric circuit, about $0.4 \mu \mathrm{A}$ flowed about $20 \mathrm{~s}$ after the switch change. In this case, the $i R$ drop is estimated to be about $0.23 \mathrm{~V}$. Since the shift of $E_{\mathrm{W} 1-\mathrm{W} 2 \text {, c }}$ was about $0.25 \mathrm{~V}$ without the resistance ( $R=0 \Omega$ ), it is easy to understand that the shift of $E_{\mathrm{W} 1-\mathrm{W} 2, \mathrm{C}}$ in the case of $R=567 \mathrm{k} \Omega$ was about $0.02 \mathrm{~V}$. In addition, the decrement in the shift of $E_{\mathrm{W} 1-\mathrm{W} 2, \mathrm{C}}$ caused the decrease in the circulating current. Consequently, it is thought that the shift of $E_{\mathrm{W} 1-\mathrm{W} 2, \mathrm{C}}$ is depressed by the $i R$ drop and that the circulating current decreases with an increase in the resistance. Thus, we suppose that the $i R$ drop causes the delay and the attenuation of the propagation of the change in the membrane potential.

The influence on the signal conduction velocity of a cell body size, the axon diameter and the cell length have been reported in the nerve transmission [9-15], and it is well known that the attenuation occurs because of the solution resistance within the nerve cell in particular. Since the resistance increases with an increase in the distance between the sending-site and the 
receiving-site along the axon and with a decrease in the sectional area of the axon, the propagation of the change in the membrane potential would become hard in the nerve transmission.

\subsection{The influence of the capacitor on the propagation of the change in the membrane potential}

When some capacitors $(C=0,44,88$ and $370 \mu \mathrm{F})$ were connected with the cell system in parallel, the time-courses of $E_{\mathrm{W} 1-\mathrm{W} 2, \mathrm{C}}$ observed are shown by curves 1 to 4, respectively, of Fig. 5(a). Similarly, those of $E_{\mathrm{W} 1-\mathrm{W} 2, \text { в }}(C=0,44,88$ and $370 \mu \mathrm{F})$ were shown as curves 5 to 8, respectively, in Fig. 5(a). Since $E_{\mathrm{W} 1 \mid \mathrm{M}, \mathrm{C}}$ significantly varied, the time courses of $E_{\mathrm{W} 1 \mid \mathrm{M}, \mathrm{C}}(C=0$, 44, 88 and $370 \mu \mathrm{F}$ ) are shown as curves 1 to 4, respectively, in Fig. 4(b). The variation of the circulating current on each case with time is shown by curves 1 to 4 of Fig. 5(c). The time dependence of the current to charge the capacitors $(C=44,88$ and $370 \mu \mathrm{F})$ is expressed by gray curves 5 to 7 of Fig. 5(c). Although the temporal responses of $E_{\mathrm{W} 1-\mathrm{W} 2, \mathrm{C}}, E_{\mathrm{W} 1-\mathrm{W} 2, \mathrm{~B},} E_{\mathrm{W} 1 \mid \mathrm{M}, \mathrm{C}}$ and $i$ were delayed by the existence of each capacitor, $E_{\mathrm{W} 1-\mathrm{W} 2, \mathrm{C}}, E_{\mathrm{W} 1-\mathrm{W} 2, \mathrm{~B}}, E_{\mathrm{W} 1 \mid \mathrm{M}, \mathrm{C}}$ and $i$ arrived at the same values $(0.110 \mathrm{~V}, 0.055 \mathrm{~V}, 0.035 \mathrm{~V}$ and $3.5 \mu \mathrm{A}$, respectively) in any case $60 \mathrm{~s}$ after the switch change. When the capacitor of which capacitance was 44,88 or $370 \mu \mathrm{F}$ was used, the coulomb number was evaluated as about 8,17 or $71 \mu \mathrm{C}$, respectively, based on the analysis of curves 1 to 4 of Fig. 5(c). Since the shift of $E_{\mathrm{W} 1-\mathrm{W} 2, \mathrm{C}}$ after the switch change was about $0.20 \mathrm{~V}$, the electric charges of the capacitors $(C=44,88$ and $370 \mu \mathrm{F})$ can be estimated at 8.8, 18 and 74 $\mu \mathrm{C}$, respectively. Thus, the experimental values are almost equivalent to the calculated values. The behavior demonstrates that the charging current of any capacitor causes only the delay in

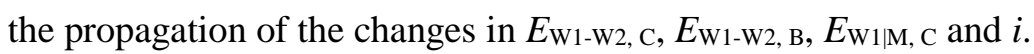

In case of neurotransmission, it is well known that the charging current occurs on the surface of lipid bilayers of nervous cells and that the charging current reduces the propagation of the action potential $[10,14]$. The decrement of the action potential propagation seems to be ascribed to the delay caused by the electric charging at the surface of lipid bilayers within axons. Since 
the open channel lifetime of voltage-gated $\mathrm{Na}^{+}$channels is about $1 \mathrm{~ms}$ [5], the circulating current caused by the $\mathrm{Na}^{+}$channels might decrease during the electric charging. It is famous that nerve conduction is promoted by the existence of myeline sheaths [21], and this facilitation seems to be caused by the decrease in electric capacity to charge the double layer on the surface of lipid bilayers.

\section{Conclusion}

In the present work, the influence on the propagation of the change in the membrane potential of the resistance and the electric charging was investigated by use of liquid membrane cell system. The propagation of the change in the membrane potential was reduced by both the potential drop prompted by generation of the circulating current and the electric charging of the capacitor within the electric circuit in analogy with the propagation of the action potential in the nerve transmission. 


\section{Notes and references}

[1] I.B. Levitan, The Neuron: Cell and Molecular Biology, Oxford University Press, New York, 2002.

[2] R. Phillips, J. Kondev, J. Theriot, Physical Biology of the Cell, Garland Science, New York, 2009.

[3] W. Schwarz, J. Rettinger, Foundations of Electrophysiology, Shaker Verlag, Germany, 2000.

[4] F. Bretschneider, J.R. de Weille, Introduction to Electrophysiological Methods and Instrumentation, Elsevier, Amsterdam, 2006.

[5] C. Egri, P. C. Ruben, Action Potentials: Generation and Propagation, eLS @, John Wiley \& Sons, 2012.

[6] G.J. Kress, S. Mennerrick, Neuroscience 2009, 158, 211.

[7] B. Hille, Ion Channels of Excitable Membranes, 3 rd ed., Sinauer Associates, Inc., Sunderland, USA, 2001.

[8] A. L. Hodgkin, A.F. Huxley, J. Physiol. 1952, 117, 500.

[9] F. Offner, A. Weineerg, G. Young, Math. Biophys. 1940, 2, 89.

[10] T. Tomita, J. Theoret. Biol. 1966, 12, 216.

[11] N. Maglaveras, F. Offner, F.J.L. van Capelle, M.A. Allessie, A.V. Sahakian, J. Electrocardiol. 1995, 28, 17.

[12] N. Sperelakis, K. P. V. Murali, Mathematical Comp. Model. 2003, 37, 1443.

[13] D. Debanne, E. Campanac, A. Bialowas, E. Carlier, G. Alcaraz, Physiol. Rev. 2011, 91, 555.

[14] R.A. Gray, D.N. Mashburn, V.Y. Sidorov, J.P. Wilkswo, Biophys. J. 2013, 104, 268.

[15] M. Delmar, D. C. Michaels, T. Johnson, J. Jalife, Circulation Research 1987, 60, 780.

[16] N. Ueya, O. Shirai, Y. Kushida, S. Tsujimura, K. Kano, J. Electroanal. Chem. 2012, 673, 8. 
[17] Y. Kushida, O. Shirai, Y. Kitazumi, K. Kano, Bull. Chem. Soc. Jpn. 2014, 87, 110.

[18] Y. Yoshida, M. Matsui, O. Shirai, K. Maeda, S. Kihara, Anal. Chim. Acta, 1998, 373, 213.

[19] Y. Yoshida, Z. Yoshida, H. Aoyagi, K. Kitatsuji, A. Uehara, S. Kihara, Anal. Chim. Acta 2002, 452, 149.

[20] Z. Samec, Pure Appl. Chem. 2004, 76, 2147.

[21] D.K. Hartline, D.R. Colman, Current Biology 2007, 17, R29. 


\section{Legends for figures and a scheme}

Fig. 1 Connection type cell composed of three liquid membrane cells (A, B and C) (a) and construction of each cell (b). Sending site: cells A and B, receiving site: cell C. W (W1 and W2); aqueous phases, M; liquid membrane (DCE). RE1-5; reference electrodes.

Fig. 2 The time-courses of the membrane potentials ( $E_{\mathrm{W} 1-\mathrm{W} 2, \text { в }}$ and $\left.E_{\mathrm{W} 1-\mathrm{W} 2, \mathrm{C}}\right)$ by changing the connection with the cell C from the cell A to the cell B (a), the potential differences at the W1|M and W2|M interfaces of the cells B and C ( $E_{\mathrm{W} 1 \mid \mathrm{M}, \mathrm{B}}, E_{\mathrm{W} 2 \mid \mathrm{M}, \mathrm{B}}, E_{\mathrm{W} 1 \mid \mathrm{M}, \mathrm{C}}$ and $\left.E_{\mathrm{W} 2 \mid \mathrm{M}, \mathrm{C}}\right)(\mathrm{b})$ and the circulating current (i) (c).

Fig. 3 Schematic voltammograms at the interfaces of $\mathrm{W} 1 \mid \mathrm{M}$ of the potential-sending cell (a), $\mathrm{W} 1 \mid \mathrm{M}$ of the potential-receiving cell (b), W2|M of the potential-sending cell (c) and W2|M of the potential-receiving cell (d).

Fig. 4 Time-courses of the membrane potentials ( $E_{\mathrm{W} 1-\mathrm{W} 2, \text { в }}$ and $\left.E_{\mathrm{W} 1-\mathrm{W} 2, \mathrm{C}}\right)$ when various resistances $(0,11,21,31,55,110,166,388$ and $550 \Omega)$ were placed in the electric circuit (a), those of $E_{\mathrm{W} 1 / \mathrm{M}, \mathrm{C}}(\mathrm{b})$ and those of the circulating current (i) (c). Curves 1-9 of (a)-(c): resistances were $0,11,21,31,55,110,166,388$ and $550 \Omega$, respectively. Curves 10-18 of (a): resistances were $0,11,21,31,55,110,166,388$ and $550 \Omega$, respectively.

Fig. 5 Time-courses of the membrane potential $\left(E_{\mathrm{W} 1-\mathrm{W} 2, \mathrm{C}}\right)$ when various condensers $(0,44,88$, and $330 \mu \mathrm{F}$ ) were placed in the electric circuit (a), those of $E_{\mathrm{W} 1 \mathrm{M}, \mathrm{C}}$ (b) and those of the circulating current (i) (c). Curves 1-4 of (a)-(c): capacitances were $0,44,88$ and $330 \mu \mathrm{F}$, respectively. Curves 5-7 of (a): capacitances were 44, 88 and $330 \mu \mathrm{F}$, respectively. 
Scheme 1 Structure of a neuron cell. 
(a)

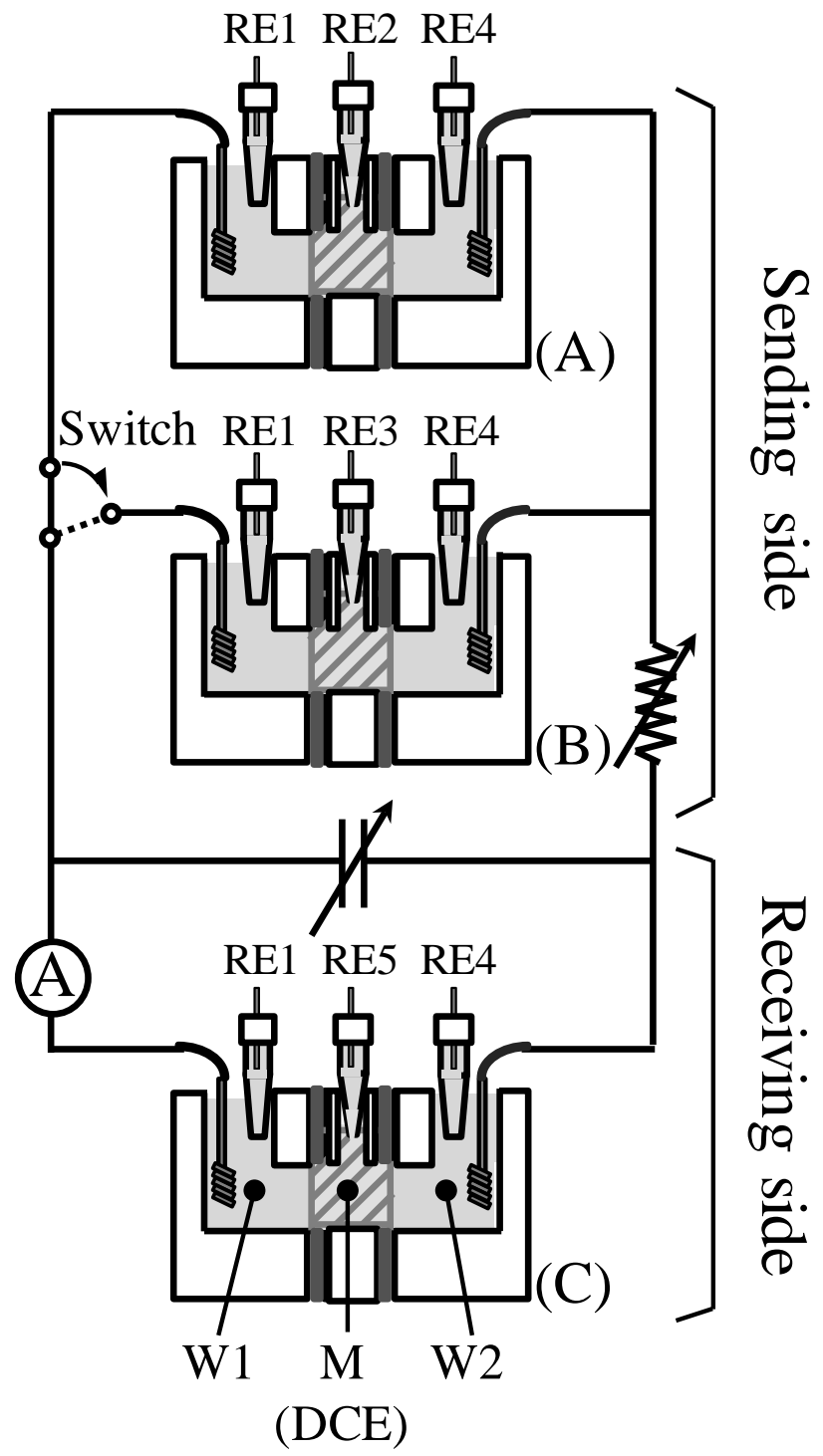

(b)

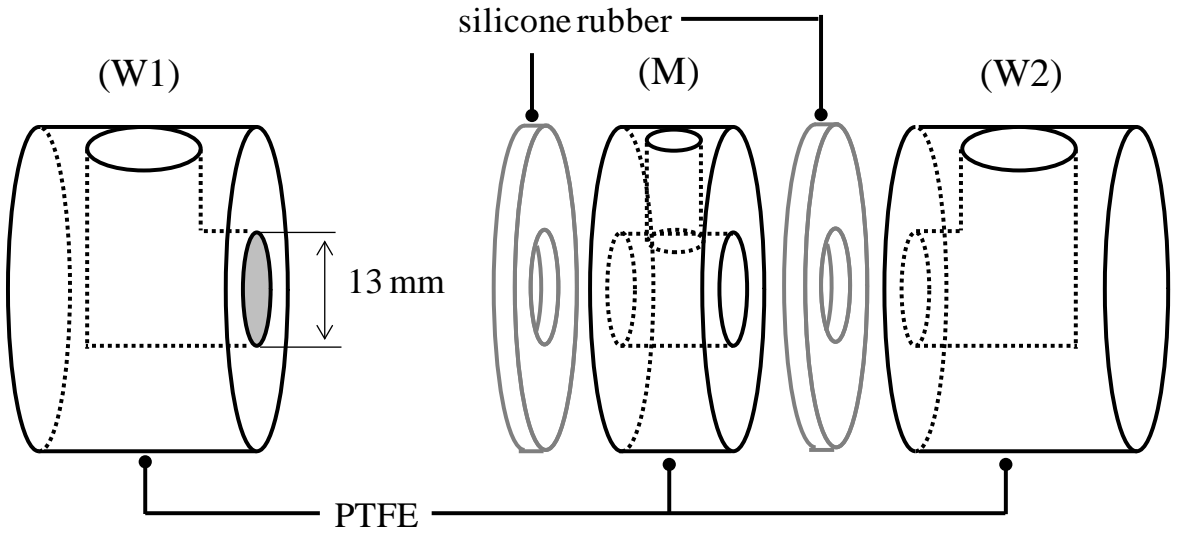

Fig. 1 Y. Kushida, et al. 
(a)

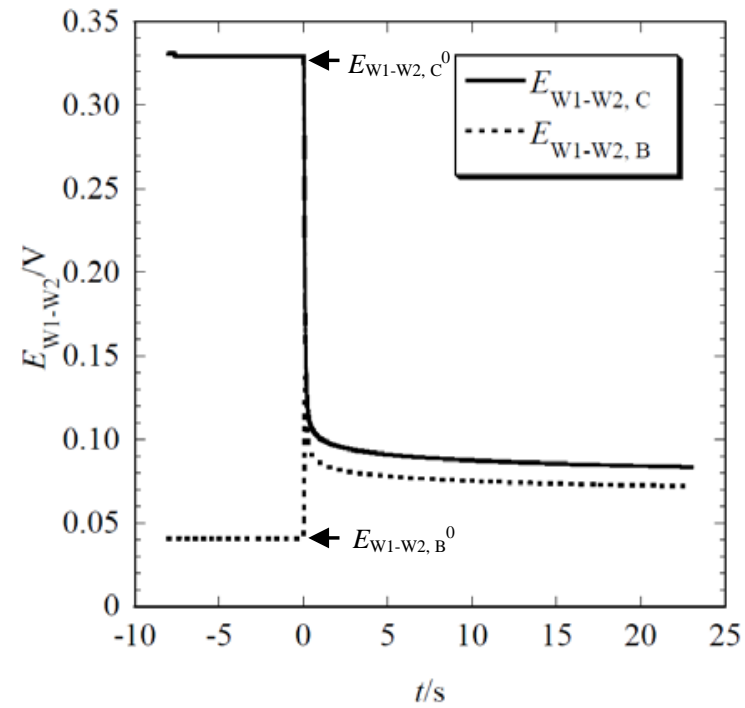

(b)

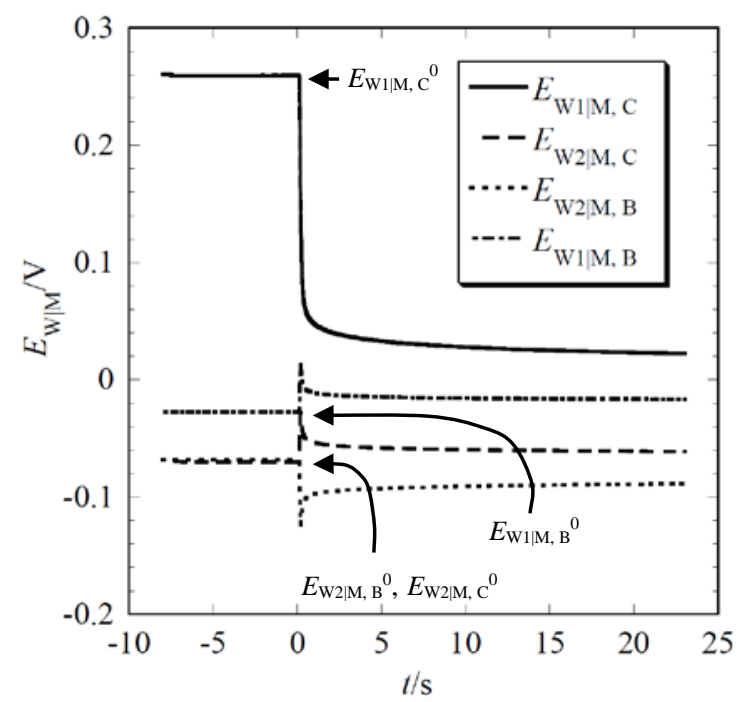

(c)

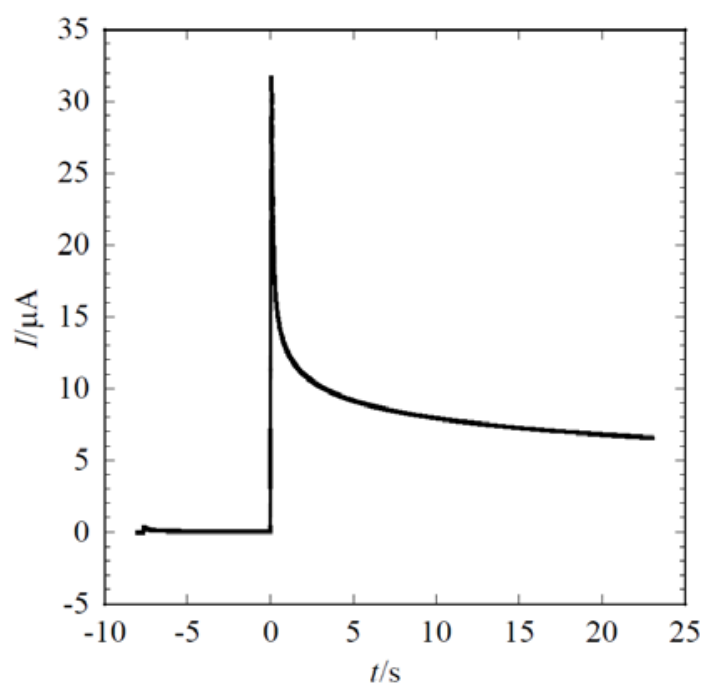

Fig. 2 Y. Kushida, et al. 
(a) Cells A and B

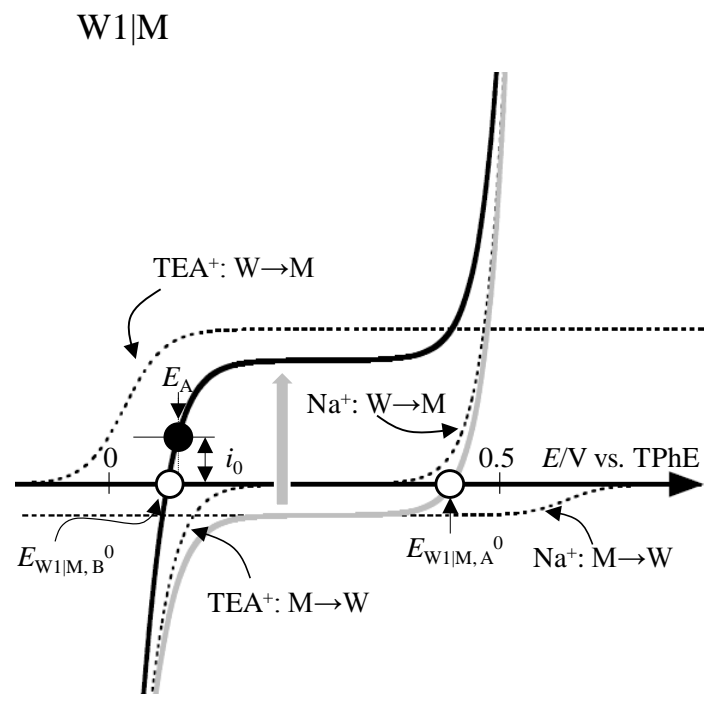

(c) Cells A and B

$\mathrm{W} 2 \mid \mathrm{M}$

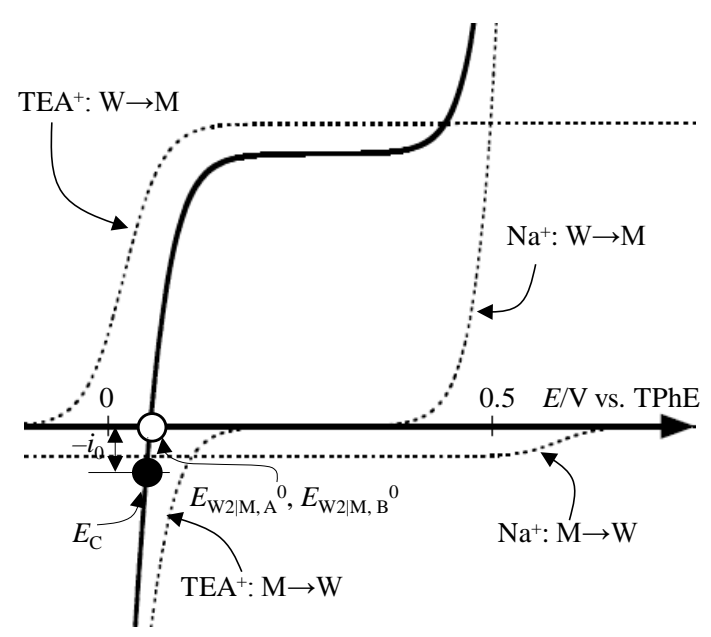

(b) Cell C

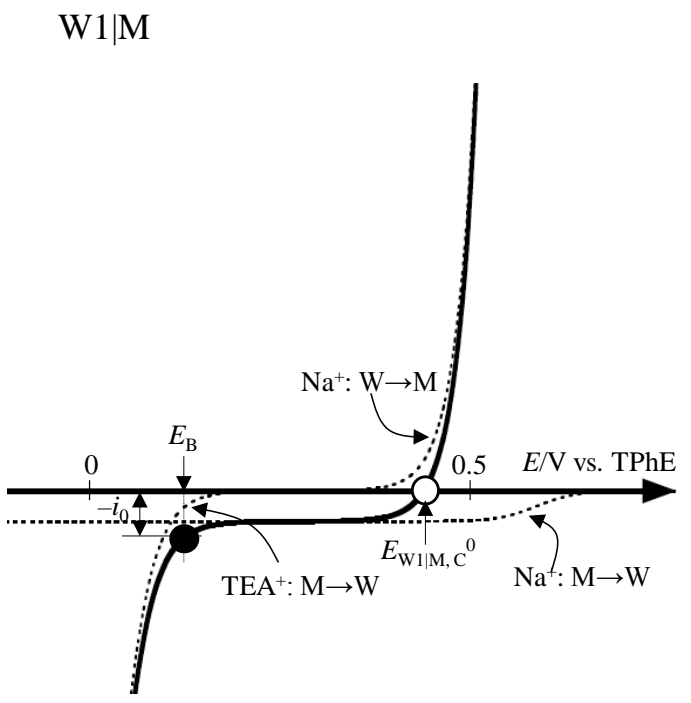

(d) Cell C

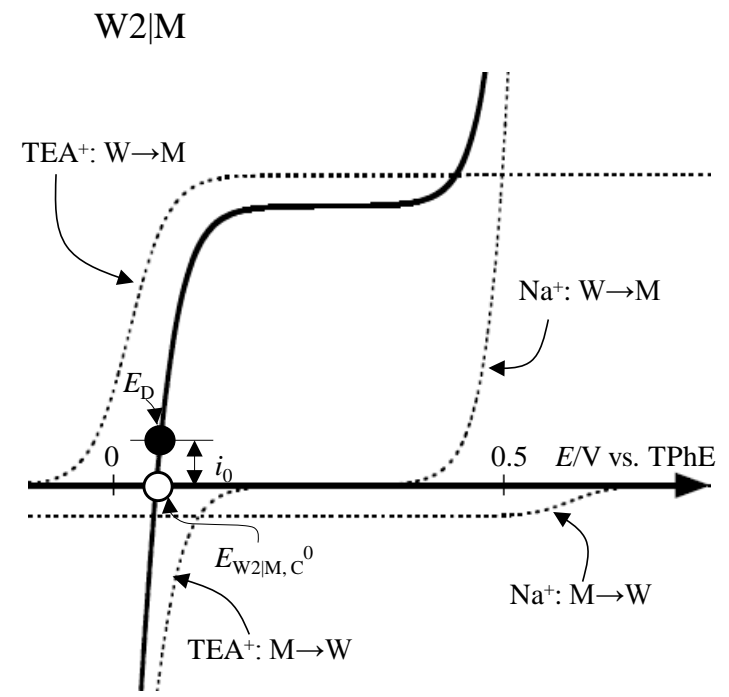

Fig. 3 Y. Kushida, et al. 
(a)

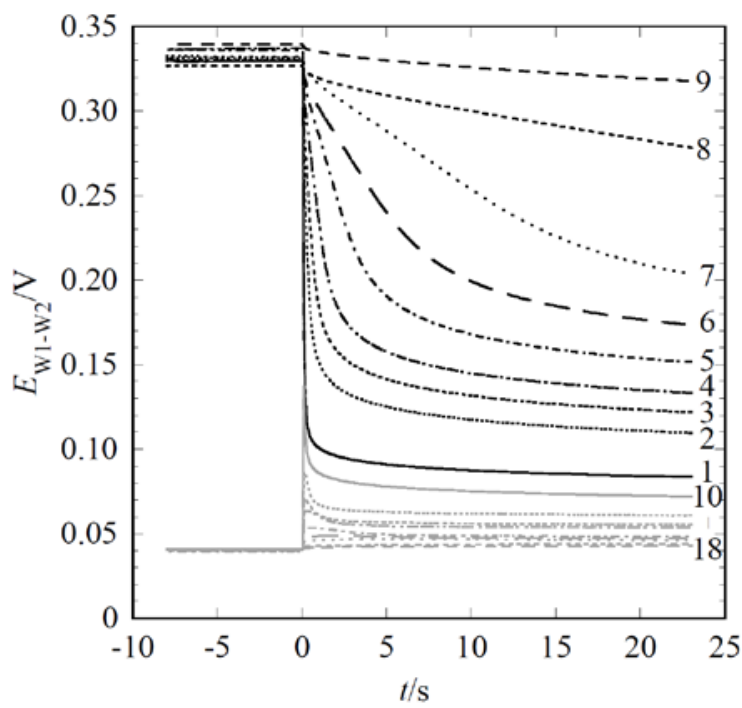

(b)

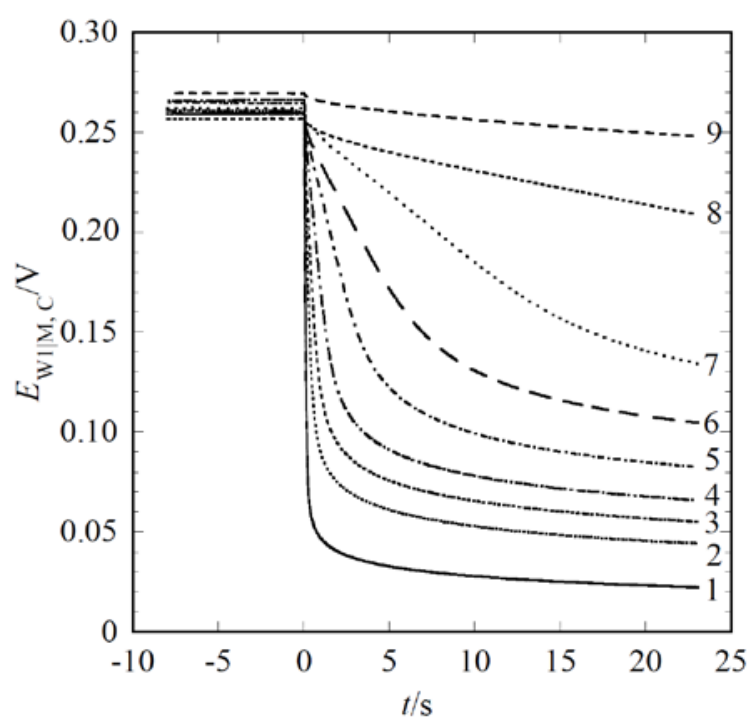

(c)

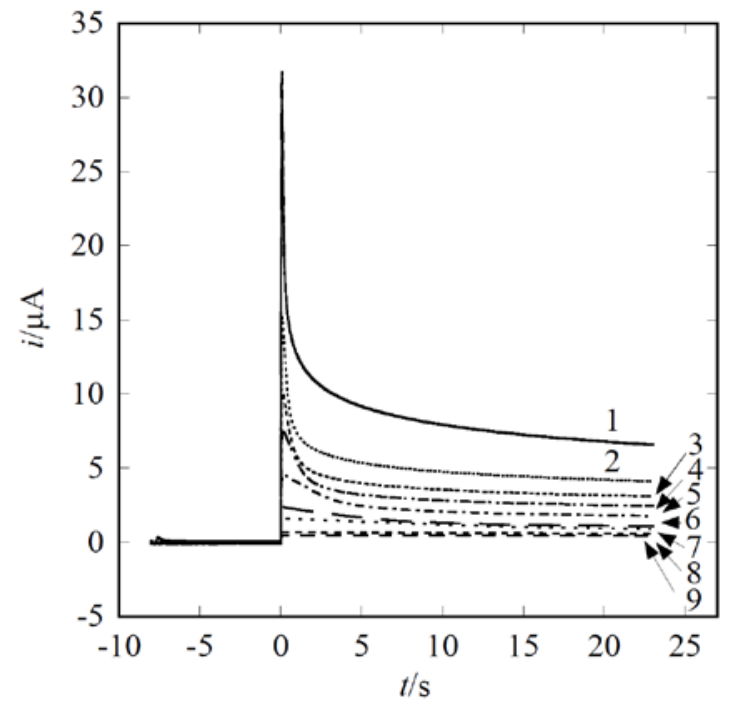

Fig. 4 Y. Kushida, et al. 
(a)

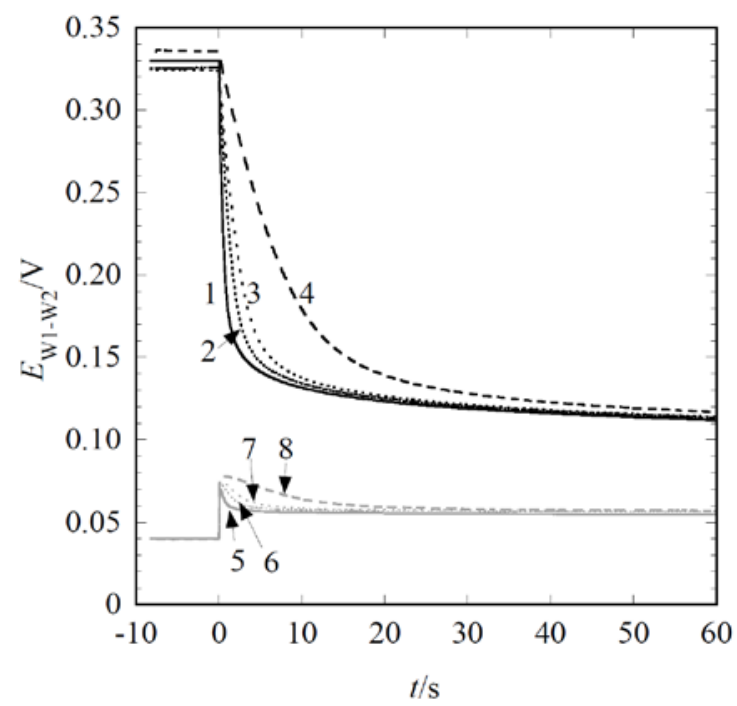

(b)

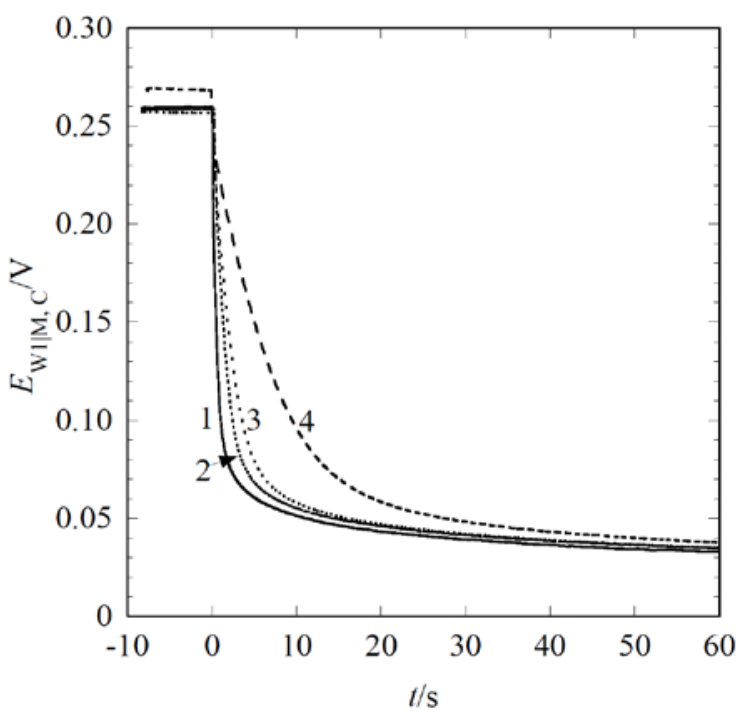

(c)

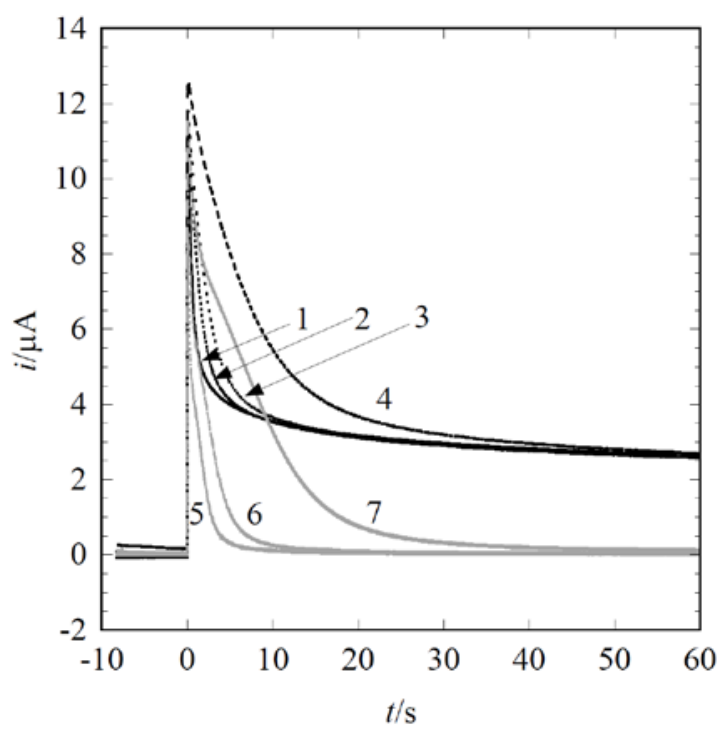

Fig. 5 Y. Kushida, et al. 


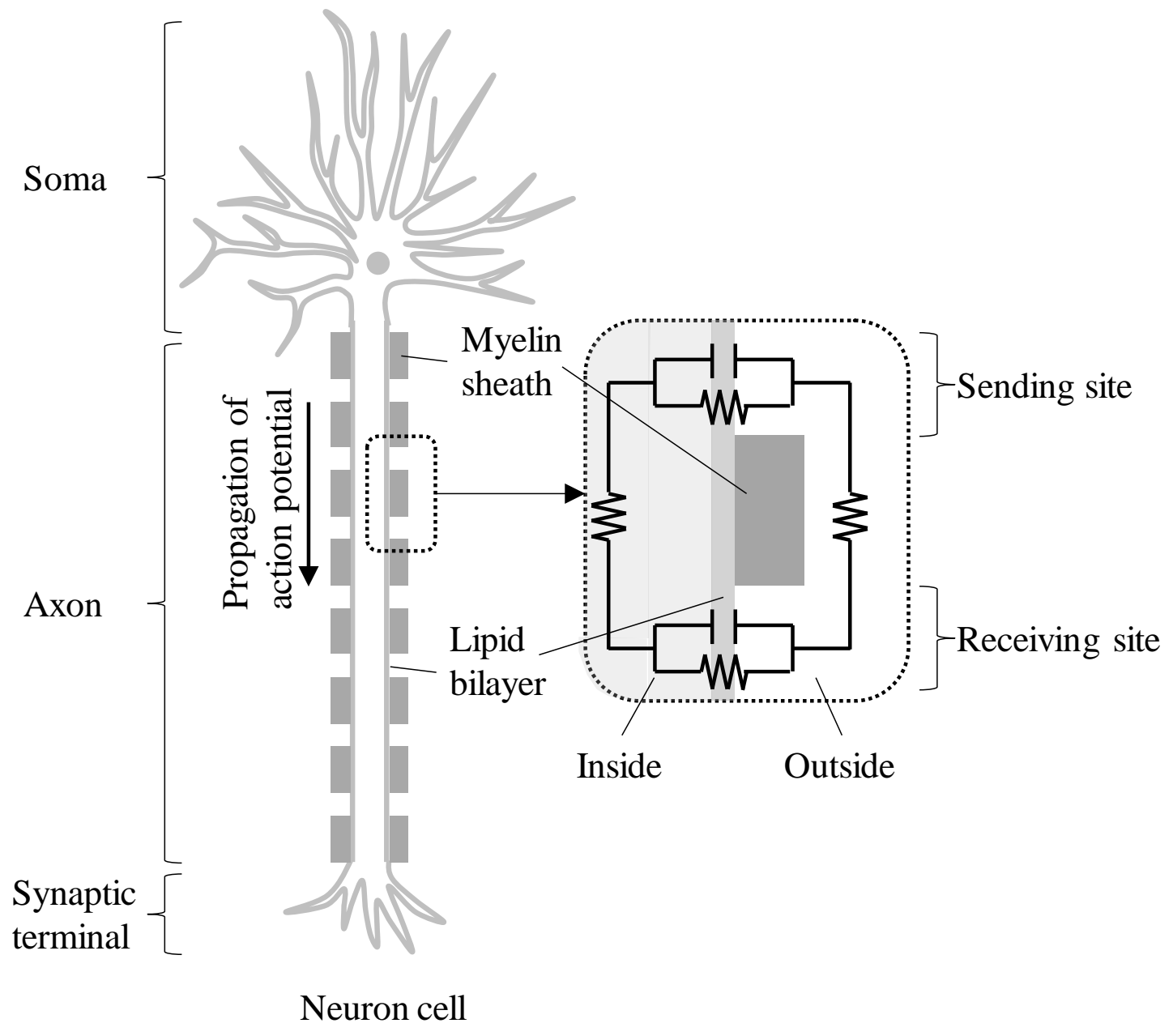

Scheme 1 Y. Kushida, et al. 